\title{
FACTORS INFLUENCING PRIVATE CUSTOMERS' TRUST IN INTERNET BANKING: CASE OF LATVIA
}

\author{
Viktorija Skvarciany \\ Vilnius Gediminas Technical University, Lithuania,viktorija.skvarciany@vgtu.lt
}

\begin{abstract}
Banking sector has developed and extended the usage of online services in the past decade. In fact, nowadays, Internet-based banking services dominate over other historically provided alternatives. This article discusses private clients' trust in Internet banking in Latvia. The model of trust in Internet banking was developed based on four factors, distinguished in the scientific literature. They are provided information, bank's characteristics, ebanking system and website of a bank. Hence, the goal of the research is to measure the impact of distinguished factors on trust in Internet banking. In order to determine how these attributes affect private customers' trust, correlation and regression analysis were applied. The results showed that the most vital factor affecting private clients' trust in Internet banking is e-banking system. What is more, it was found that provided information is a statistically insignificant factor and, hence, it was removed from the model. Respondents, being private customers, limit the breadth of study, thus the results do not reflect companies' trust in Internet banking.
\end{abstract}

Keywords: trust; Internet banking; Latvia.

JEL Classification: G21; C3.

\section{Introduction}

Scientists dealing with commercial banking sectors agree that trust is one of the decisive factors leading to successful banking activities. Trust provides collaboration between commercial bank and its clients. This allows the bank to maintain/gain a competitive advantage in the market. With increasing diversity of services provided by commercial banking, trust becomes a factor driving customer to decide whether to accept or to dismiss innovations. Because of that, it is necessary to develop/increase trust in commercial banks.

The development of e-commerce and electronic financial transactions led to the situation when the majority of companies offer intangible products. Therefore, trust in banks has become an integral part of virtual business, because none of the virtual transaction can take place without a commercial bank. Users choose a virtual service as well as select a bank through which the payment will be made. The choice of commercial bank is intertwined with trust. For this reason, whilst analysing trust in commercial banks, it is necessary to pay attention to Internet banking, as it is one of the most developing services of banks and it is becoming more popular amongst users. In fact, Internet banking is important for reaching an overall success of commercial banking activities, as many commercial banks' services are provided online. Internet banking is one of the most popular banking forms in Latvia, as it helps to reduce costs and develop completely different services for clients. Hence, it is important to encourage customers to use Internet banking in order to provide them with the most efficient services the bank could offer. However, not every user trusts Internet banking, which could lead to the refusal to use Internet banking. That is why it is important to analyse the factors influencing customers' trust in Internet banking. Actually, many researches regarding interface between trust in Internet banking and customers' intention to use it were conducted during the past decade. In fact, many scientists claim that trust has a positive direct impact on clients' intention to use Internet banking (Aldás-Manzano, Lassala-Navarré, Ruiz-Mafé \& Sanz-Blas, 2009; Bashir \& Madhavaiah, 2014; Brar, Sharma \& Khurmi, 2013; Casaló, Flavián \& Guinalíu, 2008; Chong, Ooi, Lin \& Tan, 2010; Ong \& Lin, 2015; Özkan, Bindusara \& Hackney, 2010; Suvanto, 2012; Thakur, 2014; Yiga \& Cha, 2014). What is more, Özkan et al. (2010) state that trust is the factor that affects customers' 
further intention to use Internet banking. As trust is considered to be a crucial factor having impact on success of Internet services, it is necessary to determine what leads to higher trust level. Consequently, the aim of the research is to create a model of private customers' trust in Internet banking. The objectives of the study are (1) to distinguish the factors that influence customers' trust and (2) to test the developed theoretical model of trust formation in Latvia. The current article contributes to the scope of knowledge regarding factors having impact on trust in Internet banking, and the research results provide the basis for the future studies in the related field.

\section{Literature Review}

There are scientists considering satisfaction an important factor that influences trust in Internet banking (Kassim \& Abdullah, 2010; Loureiro, Francisco \& Breazeale, 2014; Shao Yeh \& Li, 2009; Yap, Wong, Loh \& Bak, 2010a). According to the research conducted by Butt and Aftab (2013), satisfaction is the factor that helps to enhance customers' trust in virtual space. In fact, satisfaction and trust are directly proportional variables, suggesting that if the customer is satisfied with the online services provided by bank, he or she will probably use it again. Using always the same services means that the user feels safe, that is, he or she trusts the service provider. Yap, Wong, Loh and Bak (2010b) state that perceived usefulness of Internet banking is the factor affecting the level of customers' trust.

Yap et al. (2010) claim that perceived usefulness of Internet banking positively effects the level of customers' trust. Akhlaq and Ahmed (2013), whilst studying Internet banking, stated that motivation positively influences trust. Zhu and Chen (2012) determined fairness as a factor that has a positive impact on consumers' trust. Yap et al. (2010) state that trust in e-banking is influenced by perceived security and privacy of bank's website, perceived usefulness of Internet banking and website's ease of use. Liébana-Cabanillas, Muñoz-Leiva and Rejón-Guardia (2013) mention ease of use and accessibility of e-banking website as factors that develop trust in Internet banking. Yu, Balaji and Khong (2015) distinguish the following factors influencing trust-building process: goodwill, employees' competence, integrity (the service provider's interest in the client's welfare) and shared values. Zhao, Koenig-Lewis, Hanmer-Lloyd and Ward (2010) state that there is a substantial relationship between trust and perceived risk, considering that trust and perceived risk are the elements explaining clients' intention to use e-banking services. Susanto, Lee, Zo and Ciganek (2013) mention the following factors that influence trust formation in Internet banking: perceived benefits, perceived security, perceived privacy, bank's reputation and ease of use of a website. Lee and Moghavvemi (2015) found that there is a positive relationship between clients' trust and the bank's image, that is, image influences the level of trust. In order to easily understand the factors of trust in Internet banking formation, all the factors were merged into four groups:

1. Information:

- transparency

- quality

- reliability

2. E-banking system:

- perceived usefulness,

- satisfaction with the services

- internal clients' motivation to use e-banking system

- fairness

3. Bank's website:

- security

- privacy 
- ease of use

4. Service provider / the bank:

- Reputation

- image

- goodwill

- competence of employees

- integrity

- shared values

To sum up, four factors from the scientific literature are analysed and passed on to the Latvian respondents for evaluation.

\section{Methodology}

One of the main methods used in social studies is questionnaire. Questionnaire is a set of formalised questions used in obtaining information from respondents (Dikčius, 2011). After respondents complete the survey, their answers are summarised and conclusions that reflect the opinion of whole population are drawn. What is more, there are many questionnaire forms, for instance, in-depth interview, which could be conducted in person, by phone, by e-mail and so on. However, online survey is the most popular form of interview, as it could help to connect with the right number of respondents easier.

In order to get the answers that most accurately reflect the situation, the questions ought to be properly formulated. Moreover, questions should be formulated in such a way that respondent understands them correctly, because only then the analysis of the views of the respondents could be reliable.

For the purpose of getting the reliable research results, the right method of assessment should be chosen for respondents' views. There are many scientists who use the Stapel scale method (Ahmed et al. \& Hasan, 2014; Sreejesh et al., 2014), semantic differential scale method (Ciabuca, 2015; Kahveci, 2015) and Likert scale method (Breffle et al., 2011; Petsky et al., 2012). However, Likert scale remains the most popular scale whilst conducting researches. A researcher who uses the Likert scale provides a respondent with statements that ought to be evaluated. The respondent should assess the statements based on a five-point Likert scale, that is, the respondent has to indicate the degree of his or her agreement or disagreement with the statements. In other words, the factors provided to the respondents are measured with five-point Likert scale, that is, the respondents should indicate the level of their agreement with the statement that the certain factor influences the level of trust in Internet banking.

What is more, in order to obtain the reliable research results, the size of the sample ought to be stated. The number of respondents in the sample is calculated using equation (1):

$$
n=\frac{1}{\Delta^{2}+\frac{1}{N}},
$$

where

$$
\begin{aligned}
& n \text { - sample size } \\
& N \text { - general population } \\
& \Delta \text { - margin of error. }
\end{aligned}
$$

In order to estimate the strength of the relationship between two variables, a correlation analysis was used. Correlation coefficient $r_{x y}$ ranges between -1 and 1 . The further the value of the coefficient is from 0 , the stronger is the relationship between the variables. The sign of the correlation coefficient $r_{x y}$ quantifies the direction of the linear association. The formula for the correlation coefficient calculation is presented in equation (2): 


$$
r_{x y}=\frac{\operatorname{Cov}(x, y)}{\sqrt{s_{x}^{2} \cdot s_{y}^{2}}}
$$

where

$\operatorname{Cov}(x, y)-\operatorname{covariance}$ of $x$ and $y$

$s_{x}^{2}$ and $s_{y}^{2}-$ the sample variance of $x$ and $y$

One of the most important tasks of the research is to set the level of the strength of the relationship between examined factors. For the purpose of reaching this objective, the correlation and regression analyses are conducted. The correlation shows the level of the strength of the relationship and the direction of the relationship, whilst the regression explains the interface between dependent and independent variables. In order to explain the correlation coefficient, that is, the strength of the relationship, the characteristics presented in Table 1 are used.

Table 1. Qualitative characteristics of the level of strength of relationship (Source: Bartosevičienè (2010))

\begin{tabular}{|l|l|l|l|l|}
\hline $\begin{array}{l}\text { Quantitative characteristics of } \\
\text { correlation coefficient }\end{array}$ & Under 0.3 & $0.3-0.7$ & $0.7-0.9$ & $0.9-0.99$ \\
\hline $\begin{array}{l}\text { Qualitative characteristics of } \\
\text { correlation coefficient }\end{array}$ & Weak & Moderate & Strong & Very strong \\
\hline
\end{tabular}

In order to determine the level of the relationship, Pearson linear coefficient of correlation is used. The coefficient is obtained with SPPS Statistic software's function Correlate. In order to check whether the coefficient is statistically significant, Student's test is used. Before conducting the correlation analysis, two hypotheses are stated:

$\mathbf{H}_{\mathbf{0}}$ : correlation coefficient is equal to zero $\left(r_{x y}=0\right)$

$\mathbf{H}_{\mathbf{a}}$ : correlation coefficient is not equal to zero $\left(r_{x y} \neq 0\right)$

The study examines one dependent variable, which is customers' trust in Internet banking $\left(\mathrm{Y}_{1}\right)$, and four independent variables: provided information $\left(\mathrm{X}_{1}\right)$, e-banking system $\left(\mathrm{X}_{2}\right)$, bank's website $\left(\mathrm{X}_{3}\right)$ and service provider/the bank $\left(\mathrm{X}_{4}\right)$. In order to determine the level of impact of all independent variables on the dependent variable, the regression analysis is applied. In the current study, a multiple regression analysis is used (3) (Pabedinskaite, 2009).

$$
\hat{y}=a_{0}+\sum_{i=1}^{n} a_{i} x_{i}
$$

where

$\hat{y}$ - dependent variable

$a_{0}-$ constant

$a_{1}, a_{2}, \ldots, a_{n}$ - coefficient of independent variable

$x_{1}, x_{2}, \ldots, x_{n}$-independent variable

$n$ - number of independent variables

In order to describe the obtained regression model, the following criteria are used (Čekanavičius \& Murauskas, 2014; Cohen, Cohen, West \& Aiken, 2003):

Coefficient of determination, $R^{2}$. The coefficient of determination is a number that indicates the proportion of the variance in the dependent variable that could be predicted from the independent 
variables. The coefficient of determination ranges between 0 and 1 . The determination coefficient should fulfil the condition $R^{2} \geq 0.20$.

Analysis of Variance (ANOVA) p-value. The indicator shows if there are independent variables in the model that are connected to dependent variable. If the value of $p$ is greater than 0.05 , it means that $Y$ does not depend on $X$. If the value of $p$ is less than 0.05 , it means that there is at least one independent variable $X$ on which the dependent variable $Y$ depends.

Student-test. The test shows if independent variable $X$ is statistically significant. If the indicator is less than 0.05 , the examined $X$ is statistically significant, and if the indicator is greater than 0.05 , the examined dependent variable is insignificant and could be eliminated from the model.

Variance inflation factor (VIF). VIF helps to detect if there is multicollinearity between independent variables. If VIF is greater than 4 , it shows that there is multicollinearity problem, and the model ought to be modified.

\section{Empirical Findings}

To start the survey, the size of the sample ought to be computed. It was calculated by applying formula (1) and is equal to 350 . The confidence level is $95 \%$ and the confidence interval is 5.23 . In fact, 351 answers were obtained from the survey.

Whilst examining customers' trust in Internet banking $(Y)$, four factors that were presented in theoretical part of the current study are analysed: (1) provided information $\left(\mathrm{X}_{1}\right) ;(2)$ e-banking system $\left(\mathrm{X}_{2}\right)$; (3) website of a bank $\left(\mathrm{X}_{3}\right)$; (4) bank's characteristics $\left(\mathrm{X}_{4}\right)$.

Correlation coefficients between the distinguished factors and trust in Internet banking are presented in Table 2.

Table 2. Correlation coefficients between distinguished factors and trust in Internet banking in Latvia (Source: author's calculations)

\begin{tabular}{|l|l|l|l|l|l|}
\hline \multicolumn{2}{|c|}{} & $\begin{array}{l}\text { Provided } \\
\text { information }\end{array}$ & $\begin{array}{l}\text { E-banking } \\
\text { system }\end{array}$ & Bank's website & $\begin{array}{l}\text { The bank's } \\
\text { characteristics }\end{array}$ \\
\hline \multirow{2}{*}{\begin{tabular}{l} 
Trust $\begin{array}{l}\text { Internet } \\
\text { banking }\end{array}$ \\
\cline { 3 - 6 }
\end{tabular}} & $r_{x y}$ & $0.519^{*}$ & $0.658^{*}$ & $0.652^{*}$ & $0.617^{*}$ \\
\cline { 2 - 6 } & $\begin{array}{l}\text { Significance } \\
\text { (two-tailed) }\end{array}$ & 0.000 & 0.000 & 0.000 & 0.000 \\
\cline { 2 - 6 } & $\mathrm{N}$ & 344 & 344 & 344 & 344 \\
\hline
\end{tabular}

"Correlation is significant at significance level of 0.01 .

Table 2 depicts that all the correlation coefficients are significant at significance level of 0.01 . Whilst analysing correlation coefficients, it could be seen that there is a moderate direct relationship between provided information and trust in Internet banking $\left(r_{x y}=0.519\right)$. What is more, there is a strong direct relationship between trust in Internet banking and e-banking system $\left(r_{x y}=0.658\right)$. In other words, the higher is the level of perceived usefulness, customers' satisfaction with bank's provided services and internal clients' motivation to use e-banking system, the higher is the level of trust. Moreover, according to the correlation coefficients matrix (see Table 2), there is a positive direct relationship between trust in Internet banking and commercial bank's website $\left(r_{x y}=0.652\right)$. The website of commercial bank is presented through proxy variables, such as website's security, privacy and ease of use. This is to say, the more secure the customer feels and the easier it is to use the website, the higher is the level of trust in Internet banking. There is a direct positive relationship between the bank's characteristics and trust in Internet banking as well $\left(r_{x y}=0.617\right)$. This is to say, the level of customers' trust in Internet banking depends on commercial bank's image, reputation, good customer services and so on. In all the cases, the correlation coefficients are greater than zero, 
implying that the null hypothesis that the correlation coefficient is equal to zero is rejected $($ Significance $($ two-tailed $)=0.000<0.01)$.

Table 3. Multicollinearity statistics (Source: author's calculations)

\begin{tabular}{|l|l|l|l|l|}
\hline & $\begin{array}{l}\text { Information } \\
\text { provided }\end{array}$ & $\begin{array}{l}\text { E-banking } \\
\text { system }\end{array}$ & Website & $\begin{array}{l}\text { The bank's } \\
\text { characteristics }\end{array}$ \\
\hline VIF & 2.016 & 2.553 & 2.937 & 2.559 \\
\hline
\end{tabular}

It can be seen from Table 3 that all the VIFs are less than 4, which means that there is no multicollinearity and all the predictors could be used for the regression model development. What is more, ANOVA p-value is 0.000 , denoting that there is at least one dependent variable $X$ which is linked to independent variable $Y$. Moreover, the coefficient of determination $\mathrm{R}^{2}$ is equal to 0.519 , which means that the regression equation explains $51.9 \%$ of the data. The developed regression model is presented in equation (4):

$$
Y=0.585+0.373 X_{2}+0.242 X_{3}+0.199 X_{4}
$$

From the regression equation (4), it is clear that the information provided for customers $\left(\mathrm{X}_{1}\right)$ is not included in the model. In fact, the dependent variable $\mathrm{X}_{1}$ has appeared to be insignificant. However, there is one variable that is statistically insignificant - the information provided to customers. In other words, the information provided by the bank has no impact on clients' trust in Internet banking. It could be explained by the fact that provided information is majorly associated with traditional banking. All the rest variables are statistically significant, so they do have influence on trust of Latvia's residents in Internet banking.

\section{Conclusions}

Analysing the scientific literature on trust in Internet banking showed that trust is one of the vital factors of successful activities in commercial banks. It helps the bank to retain present customers as well as to attract new ones. Four factors influencing trust in Internet banking were examined. They are provided information, e-banking system, bank's website and bank's characteristics. Whilst studying these factors, regression equation was created. Moreover, it was found that the information provided to customers is statistically insignificant factor and, therefore, it was eliminated from the regression model. In fact, it was found that e-banking system is the factor having a major impact on the level of customers' trust in Internet banking in Latvia. Actually, the regression analysis showed that the trust in Internet banking is a compilation of e-banking system, bank's website and bank's characteristics. Therefore, the current study contributes to the expansion of practical knowledge regarding factors affecting the level of customers' trust in Internet banking. However, there is a limitation of the current study. The study was conducted in order to know which factors influence individual users' trust in Internet banking. However, it does not cover business companies in that issue. Therefore, the further research might be conducted in order to examine the factors affecting companies' trust in Internet banking, as the major part of customers of commercial banks are companies. To sum up, it becomes clear that commercial banks should make efforts to improve all the variables that have an impact on customers' trust in Internet banking, as Internet banking is considered to be one of the most important services commercial banks provide.

\section{References}

Ahmed, S. U., Islam, Z., Mahtab, H., \& Hasan, I. (2014). Institutional Investment and Corporate Social Performance: Linkage towards Sustainable Development. Corporate Social Responsibility and Environmental 
Management, 21(1), 1-13. http://doi.org/10.1002/csr.1298

Akhlaq, A., \& Ahmed, E. (2013). The effect of motivation on trust in the acceptance of internet banking in a low income country. International Journal of Bank Marketing, 31(2), 115-125. http://doi.org/10.1108/02652321311298690

Aldás-Manzano, J., Lassala-Navarré, C., Ruiz-Mafé, C., \& Sanz-Blas, S. (2009). Key drivers of internet banking services use. Online Information Review, 33(4), 672-695. http://doi.org/10.1108/14684520910985675

Bartosevičienė, V. (2010). Ekonominès statistikos pagrindai. Kaunas: Technologija.

Bashir, I., \& Madhavaiah, C. (2014). Determinants of Young Consumers' Intention to Use Internet Banking Services in India. Vision: The Journal of Business Perspective, 18(3), $153-163$. http://doi.org/10.1177/0972262914538369

Brar, T. P. S., Sharma, D., \& Khurmi, S. S. (2013). Influence of Trust in Espousal of E-Banking in India. International Journal of Research in Electronics and Computer Engineering, 1(1), 9-16.

Breffle, W. S., Morey, E. R., \& Thacher, J. A. (2011). A Joint Latent-Class Model: Combining Likert-Scale Preference Statements With Choice Data to Harvest Preference Heterogeneity. Environmental and Resource Economics, 50(1), 83-110. http://doi.org/10.1007/s10640-011-9463-0

Butt, M. M. M. M., \& Aftab, M. (2013). Incorporating attitude towards Halal banking in an integrated service quality, satisfaction, trust and loyalty model in online Islamic banking context. International Journal of Bank Marketing, 31(1), 6-23. http://doi.org/10.1108/02652321311292029

Casaló, L. V., Flavián, C., \& Guinalíu, M. (2008). The role of satisfaction and website usability in developing customer loyalty and positive word-of-mouth in the e-banking services. International Journal of Bank Marketing, 26(6), 399-417. http://doi.org/10.1108/02652320810902433

Čekanavičius, V., \& Murauskas, G. (2014). Taikomoji regresine analizé socialiniuose tyrimuose. Vilnius: Vilniaus universitetas.

Chong, A. Y.-L., Ooi, K.-B., Lin, B., \& Tan, B.-I. (2010). Online banking adoption: an empirical analysis. International Journal of Bank Marketing, 28(4), 267-287. http://doi.org/10.1108/02652321011054963

Ciabuca, A. (2015). The Development of a Semantic Differential Scale for Assessing the Perceived Image of Citizens about Romanian Police Forces. Procedia - Social and Behavioral Sciences, 187(PG-28-33), $28-33$. http://doi.org/http://dx.doi.org/10.1016/j.sbspro.2015.03.006

Cohen, J., Cohen, P., West, S. G., \& Aiken, L. S. (2003). Applied Multiple Regression/Correlation Analysis for the Behavioral Sciences (2nd ed.). Mahwah: Lawrence Erlbaum Associates, Inc.

Dikčius, V. (2011). Anketos sudarymo principai. Vilnius. Retrieved from http://www.ef.vu.1t/dokumentai/katedros/Rinkodaros_katedra/Medziaga_studentams/Anketos_sudarymo_princip ai.pdf

Kahveci, A. (2015). Assessing high school students' attitudes toward chemistry with a shortened semantic differential. Chem. Educ. Res. Pract., 16(2), 283-292. http://doi.org/10.1039/C4RP00186A

Kassim, N., \& Abdullah, N. A. (2010). The effect of perceived service quality dimensions on customer satisfaction, trust, and loyalty in e-commerce settings: A cross cultural analysis. Asia Pacific Journal of Marketing and Logistics, 22(3), 351-371. http://doi.org/10.1108/13555851011062269

Lee, S. P., \& Moghavvemi, S. (2015). The dimension of service quality and its impact on customer satisfaction, trust, and loyalty: A case of Malaysian banks. Asian Journal of Business and Accounting, 8(2), 91-121.

Liébana-Cabanillas, F., Muñoz-Leiva, F., \& Rejón-Guardia, F. (2013). The determinants of satisfaction with ebanking. Industrial Management \& Data Systems, 113(5), 750-767. http://doi.org/10.1108/02635571311324188

Loureiro, S. M. C., Francisco, J. M., \& Breazeale, M. (2014). Who needs delight? Journal of Service Management, 25(1), 101-124. http://doi.org/10.1108/JOSM-06-2012-0106

Ong, C.-S., \& Lin, Y.-L. (2015). Security, Risk, and Trust in Individuals' Internet Banking Adoption: an Integrated Model. International Journal of Electronic Commerce Studies, 6(2), 343-356. http://doi.org/10.7903/ijecs. 1428

Özkan, S., Bindusara, G., \& Hackney, R. (2010). Facilitating the adoption of e-payment systems: theoretical constructs and empirical analysis. Journal of Enterprise Information Management, 23(3), $305-325$. 
http://doi.org/10.1108/17410391011036085

Pabedinskaite, A. (2009). Kiekybiniai sprendimu metodai. Vilnius: Vilniaus Gedimino technikos universitetas.

Petsky, H. L., Cates, C. J., Lasserson, T. J., Li, A. M., Turner, C., Kynaston, J. A., \& Chang, A. B. (2012). A systematic review and meta-analysis: tailoring asthma treatment on eosinophilic markers (exhaled nitric oxide or sputum eosinophils). Thorax, 67(3), 199-208. http://doi.org/10.1136/thx.2010.135574

Shao Yeh, Y., \& Li, Y. (2009). Building trust in m-commerce: contributions from quality and satisfaction. Online Information Review, 33(6), 1066-1086. http://doi.org/10.1108/14684520911011016

Sreejesh, S., Mohapatra, S., \& Anusree, M. R. (2014). Business Research Methods: an Applied Orientation. Springer International Publishing Switzerland. Retrieved from http://dspace.elib.ntt.edu.vn/dspace/bitstream/123456789/7672/1/Business research methods.pdf

Susanto, a., Lee, H., Zo, H., \& Ciganek, a. P. (2013). User acceptance of Internet banking in Indonesia: initial trust formation. Information Development, 29(4), 309-322. http://doi.org/10.1177/0266666912467449

Suvanto, H. (2012). Constructing a typology of trust in asymmetrical food business relationships. British Food Journal, 114(7), 926-943. http://doi.org/10.1108/00070701211241536

Thakur, R. (2014). What keeps mobile banking customers loyal? International Journal of Bank Marketing, 32(7), 628-646. http://doi.org/10.1108/IJBM-07-2013-0062

Yap, K. B., Wong, D. H., Loh, C., \& Bak, R. (2010a). Offline and online banking - where to draw the line when building trust in e-banking? International Journal of Bank Marketing, 28(1), 27-46. http://doi.org/10.1108/02652321011013571

Yap, K. B., Wong, D. H., Loh, C., \& Bak, R. (2010b). Offline and online banking - where to draw the line when building trust in e-banking? International Journal of Bank Marketing, 28(1), 27-46. http://doi.org/http://dx.doi.org/10.1108/02652321011013571

Yiga, C., \& Cha, K. J. (2014). Toward understanding the importance of trust in influencing Internet banking adoption in Uganda. Information Development. http://doi.org/10.1177/0266666914563359

Yu, P. L., Balaji, M. S., \& Khong, K. W. (2015). Building trust in internet banking: a trustworthiness perspective. Industrial Management \& Data Systems, 115(2), 235-252. http://doi.org/10.1108/IMDS-09-20140262

Zhao, A. L., Koenig-Lewis, N., Hanmer-Lloyd, S., \& Ward, P. (2010). Adoption of internet banking services in China: is it all about trust? International Journal of Bank Marketing, 28(1), 7-26. http://doi.org/10.1108/02652321011013562

Zhu, Y., \& Chen, H. (2012). Service fairness and customer satisfaction in internet banking: Exploring the mediating effects of trust and customer value. Internet Research, 22(4), 482-498. http://doi.org/10.1108/10662241211251006 